\title{
Corrigendum: Perception of the Zika virus infection and its influence on Zika prevention practices by pregnant women at the Region 5 Health Promotion Center in Thailand
}

\author{
Issara Siramaneerat
}

Department of Social Science, Faculty of Liberal Arts, Rajamangala University of Technology Thanyaburi, Thailand

Correction to: Medical Journal of Indonesia. 2018;27(3):201-8

https://doi.org/10.13-181/mji.v27i3.2424

In the previous published article, ${ }^{1}$ there were three errors.

The first error was published on page 201 , in the results section of the abstract. the result section from the abstract, the following text appears: "The findings indicated that 5 of 12 factors could significantly predict Zika prevention practices of pregnant women at the Health Promotion Center Region 5 in Thailand: education, smoking behavior, check-up status during pregnancy, perception of susceptibility, and perception of benefit." The text was incorrect and should have read: "The findings indicated that 4 of 11 factors could significantly predict Zika prevention practices of pregnant women at the Health Promotion Center Region 5 in Thailand: education, check-up status during pregnancy, perception of susceptibility, and perception of benefit."
The second error was published on page 204, left column, first paragraph. In the first paragraph, the following text appears: "The respondents were classified into six age categories: $18-20$ years, 2125 years, $26-30$ years, $31-35$ years, $36-40$ years, and $>40$ years old." The text was incorrect and should have read: "The respondents were classified into five age categories: $18-20$ years, $21-25$ years, $26-30$ years, $31-35$ years and $\geq 36$ years old."

The third error was published on page 205, in table 1 , subheading age. It should have read as presented below (Table 1).

\section{REFERENCES}

1. Siramaneerat I. Perception of the Zika virus infection and its influence on Zika prevention practices by pregnant women at the Region 5 Health Promotion Center in Thailand. Med J Indones. 2018;27(3):201-8.

Table 1. Social determinant, perception, knowledge and preventive practice of Zika

\begin{tabular}{|c|c|c|c|c|}
\hline Characteristics & Mean \pm SD or $n(\%)$ & Coefficient & $\mathrm{p}$ & $95 \% \mathrm{CI}$ \\
\hline \multicolumn{5}{|l|}{ Age } \\
\hline 18-20 years (Ref.) & 35 (8.86\%) & - & - & - \\
\hline $21-25$ years & $62(15.7 \%)$ & -2.111 & 0.222 & $(-5.207-1.352)$ \\
\hline $26-30$ years & $91(23.04 \%)$ & -0.355 & 0.839 & $(-5.508-1.286)$ \\
\hline $31-35$ years & 147 (37.22\%) & 1.925 & 0.308 & $(-3.778-3.068)$ \\
\hline$\geq 36$ years & $60(15.18 \%)$ & 6.262 & 0.123 & $(-1.785-5.636)$ \\
\hline
\end{tabular}

pISSN: 0853-1773 • eISSN: 2252-8083 • https://doi.org/10.13181/mji.v27i4.3415 • Med J Indones. 2018;27:310 